\title{
The Purpose of the Sutton Hoo Coins
}

\author{
by PHILIP GRIERSON
}

\begin{abstract}
The chronology of the coins from Sutton Hoo is a matter of controversy on which the last word has not yet been said. They have been summarily described on several occasions, and a full account of them, and of the pattern of Frankish coinage into which they have to be fitted, can be expected in Dr F. P. C. Kent's contribution to the definitive British Museum publication on Sutton Hoo now in active preparation. In the meantime, Mr P. Grierson, Reader in Medieval Numismatics in the University of Cambridge, here puts forward a very convincing explanation of their purpose.*
\end{abstract}

The purse found at Sutton Hoo contained forty-two gold objects. Thirty-seven of them were Merovingian coins of the last decades of the 6 th and the first half of the 7 th century, three were unstruck circular blanks, and two were small rectangular ingots (Bruce-Mitford, I968, 47-51; Lafaurie, Ig68, $258-60$, correcting Marseilles to Arles as the mint of no. 3). The coins weigh from $I \cdot 221$ grams to $I \cdot 388$ grams-Bruce-Mitford's text by a slip reads grains-and average 1.27 g. (= 19.6 grains), the theoretical weight of the Merovingian gold coin at this period being $x \cdot 3$ grams, i.e. 20 grains. They are generally termed tremisses or trientes, this being the name of the third of the Roman solidus from which they were derived, but they were in fact somewhat lighter-I·3 g. as against $\mathrm{I} \cdot 5 \mathrm{~g}$.- -and no longer represented the Roman tremissis of eight carats but the Germanic shilling of twenty grains

* I should like to express my thanks to Mrs H. R. Ellis Davidson and Mr R. L. S. Bruce-Mitford for their kindness in reading and commenting on a preliminary draft of this paper. The discussion in the section on the size of the crew is based almost entirely on Mr Bruce-Mitford's observations, which he has most generously allowed me to use.
(Grierson, I96I, 35I-2). The three blanks, which are about the same diameter as the coins, are of much the same weight ( $1 \cdot 09 \mathrm{~g} ., \mathrm{I}^{3} 3^{8} \mathrm{~g}$., and $I \cdot 46$ g.: average, $r \cdot 3 \mathrm{I}$ g.). The ingots are heavier, weighing respectively $5.2 \mathrm{I} \mathrm{g}$. and 4.97 g., i.e. 80 grains and 76.7 grains, and are also of slightly inferior gold. It is probable that they were each intended to represent four shillings.

Discussion of the hoard has up to the present been mainly concerned with the mints and dating of the coins, more especially the latter, since it alone can provide a terminus post quem for the burial as a whole. Rather less attention has been devoted to the blanks. It has been variously suggested that they represent defaced coins intended for remelting, newly prepared blanks intended for striking, blanks rejected as being either too heavy or too light for minting, or simply pieces of gold added to the coins to bring the total in the purse up to some particular weight. None of these views carries conviction. The first two possibilities can be definitely excluded, for the blanks show no trace of any previous striking and blanks for Merovingian coins could scarcely occur in an 


\section{THE PURPOSE OF THE SUTTON HOO COINS}

English context. The third suggestion is also unacceptable, for while one of the blanks is under weight, the other two could have been cut or filed down to the correct weight in accordance with normal mint practice. The fourth is equally unlikely; if one wished to make up a particular total weight of gold, there would be no point in using three separate pieces of metal, each hammered out and cut to a fairly uniform weight. What was surely intended was not the making up of a certain weight of gold, but a certain number of coins or their equivalents. In a society in which coined money was still either unknown or rare and hard to come by, a person needing a specific sum for some particular purpose might well have to make up in such a way the total he required. In such a society, likewise, it would be a matter of little consequence to the recipient whether the money he received were coined or not.

An exact parallel to the Sutton Hoo situation is provided by the other great English coin hoard of the 7 th century, that found at Crondall in Hampshire in 1828 . We have two Igthcentury descriptions of it (Akerman, 1844; Lefroy, 1870 ), but the standard account is now that of Sutherland (r948). Here the coins seem also to have been enclosed in a purse or small bag, though no trace of this could be found at the time. The 'coins' were as follows:

Merovingian coins ( $\mathrm{r} \cdot 3 \mathrm{~g}$. each) _. 24

Anglo-Saxon coins ( $1 \cdot 3$ g. each) $\quad \ldots 69$

Byzantine tremissis $(1 \cdot 5 \mathrm{~g}$.) which had

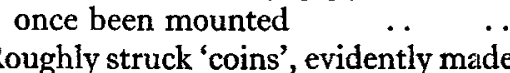

by an amateur and having no recognizable type $(\mathrm{I} \cdot 3 \mathrm{~g}$. each) $\quad . .3$

Blanks, hammered flat $(\mathrm{I} \cdot 3 \mathrm{~g}$. each). . 3

Contemporary forgery of plated copper $\mathbf{I}$

This list does not correspond exactly to Sutherland's reckoning, which requires revision on a few points of detail. His no. $I$. is not a coin of Leo I (457-74) but one of Phocas (602-10), and so less far removed in time from the other contents of the hoard. His no. 90 seems to me to fall into the same category as his no. 9I (two coins), i.e. an imitation coin without an identifiable design. He accidentally omitted one Merovingian coin, which had become separated from the rest while the hoard was in Lord Grantley's possession, and substituted for it a specimen of the 'Londonderived' series which in fact did not come from the hoard (Grierson, I953, I48-9). The forgery and the three blanks, which are known from the Akerman-Lefroy accounts, have since disappeared, but Akerman gives the weights of the blanks as $20^{\circ} 0,20.3$ and $21^{\circ} 9$ grains (average 20.9 grains).

Here I think that there can be no doubt of the intention to make up a sum of a hundred shillings. The owner originally disposed of ninety-four Frankish and Anglo-Saxon coins, one of these being a counterfeit. To these, in order to make up a hundred, he added six more pieces of the appropriate weight, three roughly struck so as to imitate coins and three simply left blank. When the sum came to be paid, it was discovered that one of the coins was a counterfeit. It had consequently to be replaced by a small Byzantine coin detached from a necklace, perhaps belonging to the owner's wife. Only in some such way can one account for the presence in the group of one exceptional coin, an import from much further afield and struck to a different weight system. One may hazard the guess that the Crondall coins represent a wergeld, the hundred shillings at which Kentish law valued the life of a man.

The forty Sutton Hoo coins must have had a different purpose, for the sum involved is negligible: less than half a free man's wergeld and far less than that of a king, less than two ounces of precious metal in a treasure so rich that the buckle alone contains over a pound of gold. There are two obvious possibilities. One, suggested to me by Mr Bruce-Mitford, is that like the later English Maundy money they were a payment reckoned in relation to the owner's age, one coin for each year of his life. The other is that they were intended to pay a precise number of persons, the likely recipients being those who rowed the ship. The first hypothesis can neither be proved 


\section{ANTIQUITY}

nor disproved; we have no idea how old the owner of the Sutton Hoo grave goods may have been. But it would obviously become less likely if the number of the coins coincided with the number of oarsmen, as in fact seems to have been the case.

\section{THE SIZE OF THE CREW}

The number of oarsmen's benches was originally estimated at nineteen, so that, as $\mathrm{Mr}$ Phillips wrote, 'the boat was probably propelled by thirty-eight rowers, the actual number depending on whether the tholes ran in unbroken sequence on each side of the boat (Phillips, 1940, I77). The tholes themselves, mere shadows at best, were not in fact everywhere visible, but could be traced fore and aft to between ribs 5 and 6 and ribs 21 and 22 . This made a total of seventeen, but it was reasonable to assume a further one at each end, bringing the total up to nineteen. Such details could not be checked when the ship was reopened in 1966-7, since the gunwale and upper strakes had slid inwards and it was not possible to establish with certainty the position of the scarfs fore and aft. The figure of nineteen pairs of oars, however, seemed well-established; it was repeated in Green's study of 1963 , where there is a detailed comparison with the Nydam ship (Green, 1963, 54), and appears again in the recent British Museum handbook (p. 79, n. 3r). It seemed to be borne out by a comparison between the size of the Sutton Hoo ship $(c .89 \mathrm{ft} .=c .27 \mathrm{~m} ., 26$ pairs of ribs) and that from Nydam ( $74 \mathrm{ft} .=22.5 \mathrm{~m}$., 19 pairs of ribs), since in the latter case there are known to have been thirty rowers.

The accuracy of such a figure was queried some years ago by Harald Akerlund (rg63, 142). He pointed out that the tholes in the provisional Science Museum drawing (fig. I9 in the current British Museum handbook) were out of step with the ribs. For structural reasons the thwarts would have to be built on to the ribs and the tholes would occur between them, so that if the tholes were spaced evenly between the ribs on the Science Museum drawing an extra pair of oars could be fitted in. The ship therefore had twenty pairs of oars, not nineteen, and thus corresponded to a tvitugsessa, a twenty-bencher, a category of ship occasionally alluded to in Old Norse literature. Thorolf Kveldulfsson, in Egil's Saga, 8, 5, went a-viking in a twenty-benched 'snake-ship' (snekkja), and the Gulathing Law, cap. 30I, lays down that if five or more of the benches of a tvitugsessa are unfilled, it shall not be adjudged seaworthy (Keyser and Munch, I 846,99 ).

This argument was in detail fallacious, for the Science Museum drawing actually showed only eighteen tholes, so that correcting the spacing would bring the number up to only nineteen. But it was fundamentally correct. On the Science Museum drawing the tholes are not carried as far forward as they are aft. The thole furthest aft, between ribs 22 and 23 , is over the aft scarf, where the keel is joined to the stern post. No thole is shown forward in the corresponding position, between ribs 3 and 4. If one is put there, the oar would cross the gunwale at a height of about $3 \mathrm{ft} .8 \mathrm{in}$. (c. $112 \mathrm{~cm}$.) above the estimated light-load waterline, i.e., the same height above the water as the furthest aft thole, between ribs 22 and 23 . The next two tholes inwards are 5 in. $(12 \cdot 7 \mathrm{~cm}$.) lower, but a $3 \mathrm{ft}$. 8 in. maximum is not an excessive height above water, especially with the vessel loaded. The four end oars would have had to be longer, or rowed steeper, than the others, but would have been quite manageable. On the basis of the Science Museum drawing, then, once the necessary correction has been made, we are back at twenty thwarts and forty oarsmen, the same number as that of the coins in the Sutton Hoo purse.

\section{USE FOR THE COINS}

There are two alternative ways in which such a use for the coins might be conceived. One is to assume that they belong to the category of household goods. A king or other person of means, when undertaking a journey, would bring with him some means of rewarding those responsible for conveying and lodging him. In this case, where the ship was rowed by forty oarsmen, one might envisage him putting forty coins in his purse, with something over- 


\section{THE PURPOSE OF THE SUTTON HOO COINS}

the two ingots-for the steersman. The other possibility is that the coins represent an unusually splendid form of Charon's obol. A lone ferryman, conveying passengers across a narrow stream, could expect no more than a single small coin from each. The forty oarsmen of a great sea-going ship might hope for rather more. Coins of gold would be a natural consequence of the rank of the donor, more especially when the uncertain length of the journey was taken into account. Gold was in any case the only metal used for coinage in western Europe in the early 7 th century, and since as many as forty coins were required it would be necessary to use contemporary ones instead of the isolated worn or obsolete silver pieces that were usually regarded as adequate to the ferryman's needs.

A material explanation is scarcely acceptable in the context of a society that made no use of coin. Oarsmen in the king's service, in $7^{\text {th- }}$ century East Anglia, would have received their reward in other ways. It is much more probable that the coins in the Sutton Hoo purse were intended for supernatural use, linking up two fairly distinct funerary practices which are normally found at different cultural levels (Ellis, 1943, 16, 39, 170; Davidson, 1964, 133; Stjerna, 1912, 97, 197; Ebert, 1919-20, 186). One is that of providing the dead with all that might be necessary for their life in another world: arms and clothing, jewellery, household goods, farm animals, and the like. The other arises out of the very widespread idea that the passage to the Other World involves a journey, which according to circumstances might be by land or sea and for which provision would have to be made (Grinsell, I957; Wilcke, 1925; Siebs, I930- $\left.1,6 \mathrm{I}_{5}\right)$. In the Mediterranean world, and surviving as a traditional practice long after its initial basis had ceased to be held as a serious belief, this found expression in Charon's obol. Interpretations of Scandinavian ship-burials have hitherto been undecided: is the ship no more than one of the dead man's possessions, intended for his life in another world, or does it represent the means by which he was to be conveyed thither? The circumstances of ship-funerals by themselves tell us little, whether the ship be buried in a mound or whether, as in the obsequies of Scyld described in the opening to Beowulf, the dead man and his gear are placed on a ship which is pushed out to sea, it being left to the higher powers to determine its fate. The Sutton Hoo coins point towards a solution. If they simply belonged to the class of grave goods representing the dead man's wealth, there would have been no need to make them up to a specific sum; the thirty-seven real coins would have been sufficient. The fact of their being made up with blanks to coincide with the number of the rowers surely implies a journey, and contact with coin-using peoples, familiar with the practice of Charon's obol, would have suggested how it should be paid for. Perhaps the first hearers of Beowulf envisaged ghostly oarsmen taking over the conduct of Scyld's funeral ship once it was out of sight of land. On such a matter the Christian Beoroulf is understandably silent, but the coins from Sutton Hoo suggest that this may have been the case.

\section{BIBLIOGRAPHY}

AKRRMAN, J. Y. I844. Description of some Merovingian, and other gold coins, discovered in the parish of Crondall, in Hampshire, in 1828 , Numismatic Chronicle, vi, $171-82$.

AKERLUND, H. 1963. Nydamskappen (Göteborg).

BRUCE-MITFORD, R. L. S. 1968. The Sutton Hoo ship burial: a handbook (The British Museum).

DAVIDSON, H. R. ELlis. 1964. Gods and myths of northern Europe (Harmondsworth).

EBERT, M. I9I9-20. Die Bootfahrt in: Jenseits, Praehistorische Zeitschrift, XI-XII, 179-96.
RLLIS (DAVIDSON), H. R. 1943. The road to Hel: a study of the conception of the dead in Old Norse literature (Cambridge).

GREEN, C. 1963. Sutton Hoo: the excavation of a royal ship burial ( 1963$)$.

GRIERson, P. I953. A stray from the Crondall hoard, Numismatic Chronicle 6 , XIII, $14^{8-9 .}$

I96r. La fonction sociale de la monnaie en Angleterre aux VII-VIIIe siècles, Moneta e scambi nell'alto medioevo ( = Settimane di studi del Centro italiano di studi sull'alto medioevo, viII, Spoleto), 34I-62. 


\section{ANTIQUITY}

GRINSELL, L. V. 1957. The ferryman and his fee: a study in ethnology, archaeology and tradition, Folk-Lore, LXVIII, 257-69.

KEYSER, R. and MUNCH, P. A. 1846. Norges Gamle Love indtil $\mathrm{I}_{387}$, I (Christiania).

LAfAURIE, J. 1968. Numismatique romaine et médiévale, Anmuaire de l'École Pratique des Hautes Etudes, I967/Ig68: IVe section, sciences historiques et philologiques (Paris), 255-63.

LEFROY, J. H. 1870. Further notice of gold coins discovered in 1828 by C. E. Lefroy, Numismatic Chronicle 2 x, $164-76$.

PHILlips, c. w. r940. The excavation of the Sutton Hoo ship-burial, Antiquaries fournal, xx, I49202.
SIEBS, T. 1930-r. Geld, in Handwörterbuch des deutschen Aberglaubens, Berlin-Leipzig, III, $590-625$.

STJERNA, K. I912. Essays on questions connected with the Old English poem of Beowulf (Viking Club, Extra Series, No. III. Coventry).

SUTHERLAND, C. H. v. 1948. Anglo-Saxon gold coinage in the light of the Crondall hoard (London).

WILCKE, G. 1925. Charonspfennig, in Max Ebert, Reallexikon der Vorgeschichte, II (Berlin), 302-3.

\section{Book Chronicle}

The Roman Army-A Wall Chart, $28^{\prime \prime} \times 36^{\prime \prime}$; 1969, ros. Sunday Times Special Projects Unit. Text by Patricia Connor, drawings by Anthony Greenwood, Neal Martin and Peter Snowball, designed by Edwin Taylor and Peter Sullivan.

An admirable production which has captured the public imagination. 2,500 people wrote for it on its first day of publication, and 12,000 copies were sold in the first ten days. Ideal for schools, University departments and Museums. It is to be followed by two other wall charts, the first on the Roman Way of Life and the second on the Norman Invasion, and we hope many more. All success to this fascinating venture.

The Ancient World at Work by Claude Mossé. 135 pp., 5 plates, I map. The Romans and Their Gods by R. M. Ogilvie, $I 35$ pp., 4 plates, 2 plans. Nero: Reality and Legend, by B. H. Warmington, 192 pp., 3 plates, 3 maps. Early Greece: The Bronze and Archaic Ages by M. I. Finley, 165 pp., 4 figs., 8 plates. 6 maps. All published London: Chatto and Windus, I970 at 2Is. (hard covers) ros. (paper). The first four volumes in a new series called Ancient Culture and Society, edited by Moses Finley, Reader in Ancient Social and Economic History in the University of Cambridge.

Medieval Civilization in Germany 8001273 by Franz H. Bauml. London: Thames and Hudson, I969. 230 pp., including 60 photographs, 39 figs., 14 maps. Vol. 67 in the 'Ancient Peoples and Places' series. 42s. $\left(£^{2.10)}\right.$

\section{PREHISTORY: An Introduction}

\section{Derek Roe}

Derek Roe presents the modern approach to prehistory. Once considered the driest of studies, prehistory has captured the public's interest and this book will be found stimulating and informative by both the student and the interested amateur. With over 140 attractive illustrations, useful maps of all the sites mentioned in the text and detailed notes for each chapter, dealing with more controversial topics, this introductory account of the main sequence of events in Old World Prehistory does not demand a special archaeological knowledge on the part of the reader, only the interest to obtain a copy and read it.

$50 \mathrm{~s}$

\section{MACMILLAN}

Man in Prehistory by Chester S. Chard. Nero York: McGraw-Hill Book Company, I969. $35 \mathrm{I}$ pp., I02 figs. and photographs. $£, 3$ I6s.

The Art of Ancient Egypt by K. Michalowski. London: Thames and Hudson, 1969. 600 pp., II 5 pls. (I43 in colour), drawings, maps and plans. fI2 I2s. (£I2.60).

continued on page 45 